\title{
Från diskriminering till jämlik behandling \\ Om könsmönster i den svenska riksdagens utskott
}

Af Lena Wängnerud

Det svenske valg $i 1994$ blev et vendepunkt for den herskende konsopdeling $i$ svensk politik og siden er den tidligere diskrimination af kvindelige politikere blevet udfordret. Men bvordan tolker man forekomsten af kvindelige og mandlige politikomraider uden at bekrafte konsfordomme i stedet for at udfordre dem?

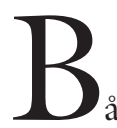

åde i forskningen och bland politiker själva pågår en debatt om kvinnors möjligheter till makt och inflytande. "Jag föreställer mig att de nya manliga riksdagsmännen kunde gå till riksdagsgruppens ledning och uttala sina önskemål” skriver Gunnel Jonäng om sin tid i Sveriges riksdag (Jonäng 1996, 233). Jonäng var ledamot under 20 år. "För varje kvinna som dels var oerfaren och dels inte var 'kompis' med de politiska storheterna var detta inte möjligt" fortsätter hon. Jonäng beskriver en verklighet där det varit svårare för kvinnor än för män att ta sig fram.

Under senare tid har det blivit vanligt att de nordiska länderna pekas ut som undantag från regeln att politik är en manlig verksamhet (Bergqvist m.fl. 1999; Norris 1996). Internationellt sett är det få kvinnor som når de högsta politiska positionerna. Genomsnittet $\mathrm{i}$ världen, när det gäller andel kvinnor i nationella parlament, är fortfarande år 2001 kvar på den låga nivån 13,8 procent. Det är samma nivå som de nordiska länderna be- 
fann sig på i början av 1970-talet. Genomsnittet i de nordiska länderna ligger idag på 37,7 procent. Högst är nivån i Sverige med 42,7 procent (http://www.ipu.org).

Syftet med denna artikel är att gå bakom den bild som den officiella statistiken över kvinnorepresentation visar upp. Fokus är på den svenska riksdagen. Artikeln handlar om den relativt okända värld som Jonäng berättar om: utskotten. En analys av den interna arena som utskotten utgör bidrar till att öka kunskapen om villkoren för kvinnors och mäns politiska arbete; vilka mekanismer som verkar särskilt hindrande för kvinnor och vad som gör att villkoren kan förändras. Det finns belägg för en tidigare diskriminering mot kvinnliga politiker men valet 1994 har inneburit en vändpunkt för den rådande könsordningen.

\section{MARGINALISERING ELLER INKLUDERING}

Det är ett genomgående tema i detta nummer av tidskriften Kvinder, Kon \& Forskning huruvida kvinnor kan betraktas som inkluderade eller fortsatt marginaliserade i nordisk politik. Statistiken över andel kvinnor i de nordiska parlamenten visar otvetydigt på en förändring, men sådana siffror riskerar att bli ytliga. Vad som gör utskotten särskilt intressanta att undersöka är att de kan fungera som ett lackmuspapper. Marginalisering och inkludering är fenomen som är svåra både att definiera och exakt mäta. Utskotten kan då utgöra en indikator på de mer osynliga mekanismer debatten handlar om.

Utskotten är ett av de mest centrala organen i riksdagens arbete. Det är där ärendena bereds innan de går till omröstning $\mathrm{i}$ kammaren och utskotten utgör en bas för de förhandlingar som pågår mellan partierna (Sannerstedt 1992). Utskotten uppfattas också av ledamöterna själva som att de har stor makt över beslutsfattandet (Esaiasson \& Holmberg 1996, 219). Det är eftertraktat att vara ordinarie ledamot. Det råder konkurrens om platserna. Men jämförs andel kvinnliga ledamöter i riksdagen som helhet med andel på ordinarie utskottsuppdrag, visar det sig att en marginalisering av kvinnor åtminstone inte tar sig uttryck som en direkt utestängning. Under hela perioden från 1971 fram till idag har kvinnor nått ordinarie ledamotskap $i$ en utsträckning som motsvarar deras andel i riksdagen (Wängnerud 1998, 52). Frågorna om inkludering och marginalisering måste därför angripas på ett annat sätt.

\section{KVINNLIGA OCH MANLIGA POLITIKOMRÅDEN}

År 1983 utgavs boken Det uferdige demokratiet (Haavio-Mannila m.fl.). Författarna, några av den tidens mest ledande kvinnoforskare, var bland de första som fäste uppmärksamhet på förhållandet att kvinnor, väl på plats i politiskt valda forum, kom att koncentreras till en viss typ av arbetsuppgifter. De kallade fenomenet för en funktionell arbetsdelning mellan kvinnor och män. Författarna ger exempel på att kvinnliga parlamentariker i Norden varit mer vanligt förekommande på uppdrag som rör socialoch utbildningsfrågor än på sådana som är ägnade åt ekonomi och näringslivspolitik. De skriver följande om orsakerna till att det blir en sådan uppdelning:

"Vi vet ikke stort om hvordan komite-plasseringene foregår. Det kan tenkes at kvinnene selv har foretrukket sosial- og undervisningskomiteene, fordi de har vært interessert i sakene, synes det er viktige og har følt seg mest kompetente på disse områdene. Det kan imidlertid også tenkes at mennene nødig har villet slippe kvinner inn på 'deres' områder, eller at konkurransen om økonomi- og næringslivskomiteene har vært så hard at kvinnene ikke har nådd opp." (Haavio-Mannila m.fl. 1983, 96)

I citatet framkommer att uppdelningen kan ha sin grund i en utestängning av kvinnliga 
politiker, att männen inte velat släppa in kvinnor på "sina" områden. Detta är en tankegång som senare utvecklats $\mathrm{i}$ teorin om genussystemet. Teorin om genussystemet är ämnad åt att identifiera vilka mekanismer som upprätthåller en ojämlik maktrelation mellan könen i ett samhälle där de formella rättigheterna är lika för kvinnor och män. Yvonne Hirdman (1990) menar att ett av de allra viktigaste inslagen i könsmaktsordningen är att kvinnors och mäns verksamheter hålls isär. Hon kallar detta för en dikotomisk princip. Tillämpat på politikens område innebär denna princip att underordningen av kvinnor upprätthålls just genom att kvinnorna, även om de blir fler, koncentreras till vissa uppgifter. Hirdman skriver:

"Naturligtvis opererar internsegregeringens mekanismer också inom det politiska området, vilket framförallt innebär att kvinnliga politiker företrädesvis finns samlade kring konsumentpolitik, socialpolitik, kulturpolitik och andra 'vårdande' eller 'reparerande' politiska områden, medan deras frånvaro är markant vad gäller till exempel försvarspolitiken.” (Hirdman 1990, 95)

I citatet beskriver Hirdman vad hon kallar för en internsegregering. Hirdman går ett steg längre än författarna till Det uferdige demokratiet. Hon skriver att de platser som tilldelats de kvinnliga politikerna varit "tomma på makt, men fyllda med ansvar" (Hirdman 1990, 114). Men teorin om genussystemet är inte det enda perspektiv som utvecklats från den tidigare kvinnoforskningen. I citatet från Det uferdige demokratiet säger författarna att uppdelningen också kan handla om att kvinnor och män gör olika val. Detta är ett perspektiv som bland annat Hege Skjeie fört vidare. I direkt polemik mot Hirdman och teorin om genussystemet skriver Skjeie att det ibland kan vara önskvärt att det föreligger en uppdelning av de politiska aktiviteterna mellan kvinnor och män:
“... det er ... ikke alltid ønskelig at kvinner og menn er 'i blant' de samme aktivitetene: i det daglige politiske arbeidet, og i konkrete beslutningssammenhenger, er det viktigt at det finnes kvinnelige politikere som interesserer seg for annet enn det menn interesserer seg for. Enkelte saksområder, har større strategisk betydning enn andre i arbeid for å realisere en bestemt politikk.” (Skjeie 1992, 60(61)

Vad som framkommer av diskussionen ovan är att det inte råder någon enighet om hur man skall tolka förekomsten av kvinnliga och manliga politikområden. Att det finns en uppdelning är både Hirdman och Skjeie eniga om, men när det gäller orsakerna till, och konsekvenserna av, uppdelningen går meningarna isär. Den skiljelinje som framträder återfinns även i internationell forskning. Sue Thomas har gjort en undersökning av amerikanska politiker på delstatsnivå, även där finns en uppdelning av kvinnliga och manliga politikområden. Thomas ställer frågan om det är eget val eller diskriminering som ligger bakom mönstret och hennes svar ligger när Skjeies, hon skriver: "it is out of choice rather than coercion or discrimination that this occured" (Thomas 1994, 67).

Om man skall komma vidare med frågorna om marginalisering och inkludering måste man ta hänsyn till de mönster som döljer sig bakom de allmänna beskrivningar som ofta görs av andel kvinnor i politiken. Den forskning som redovisas ovan är ett viktigt steg på vägen. Ett problem med den tidigare forskningen är dock att de beskrivningar som gjorts av de bakomliggande mönstren varit ganska svepande. "Kvinnligt" och "manligt" är notoriskt vaga begrepp och det är svårt att få någon mer exakt bild av hur genomgripande mönstren egentligen är, vilka områden det gäller och vilka förändringar som eventuellt äger rum över tid. Ett annat problem är att de begrepp som används ofta har en inbyggd värdering. När exempelvis Hirdman skriver om "segregering” leder själva ordvalet tanken åt ett särskilt håll. För att forskningen 
inom området skall kunna gå framåt behöver analyserna bli mer precisa. Det behövs också en tydligare åtskillnad mellan olika nivåer i forskningen, mellan exempelvis teori och empiri. I nästa steg skall jag göra en beskrivning av könsmönster i riksdagens utskott. Först därefter skall vi gå vidare med frågorna om olika förklaringar och tolkningsperspektiv.

\section{ETT KONTINUUM MELLAN}

\section{REPRODUKTION OCH PRODUKTION}

Det är ett vanskligt företag att tala om könsmönster - om "kvinnlig" eller "manlig" politik. Risken finns att man befäster olika könsfördomar istället för att utmana dem. Ett grundläggande krav för att undvika sådana fällor är att de indelningar som görs är fruktbara: man skall kunna fånga in en eventuell könsdimension samtidigt som man håller möjligheten öppen att registrera avvikelser och förändringar.

Ett tillvägagångssätt jag själv prövat i andra sammanhang har varit att avstå från att bestämma vilka utskott som förväntas vara kvinnliga eller manliga och istället utgå från den faktiska fördelningen av respektive kön och därefter rangordna utskotten från mest till minst andel kvinnor. Resultatet blir en beskrivning som helt och hållet utgår från empirin (Oskarson \& Wängnerud 1995, 106; Wängnerud 1996). Men en sådan kategorisering kan lätt bli oöverskådlig om man vill skildra utvecklingen över tid. Av skäl som delvis är metodologiska har jag därför valt att här använda en något annorlunda princip. Först görs en kategorisering av utskotten där de delas in i olika ämnesområden. Därefter sker en analys av huruvida det föreligger någon skillnad $\mathrm{i}$ andel kvinnliga respektive manliga ledamöter.

Den följande kategoriseringen utgår från begreppsparet reproduktion-produktion vilket är vanligt förekommande i analyser av kvinnors och mäns skilda positioner i samhället. Reproduktion syftar på vad som i vid mening kan sägas vara omsorgsarbetet i samhället: vård av barn och gamla, vård av sjuka etc. Produktion, i sin tur, syftar på vad som i vid mening kan sägas vara samhällets framställande av varor. Traditionellt sett har reproduktion varit ett kvinnligt ansvarsområde. Det är också ett område som i stor utsträckning varit knutet till den privata sfären. Produktionen har på ett annat sätt varit knutet till offentligheten och lönearbetet. Det har också, traditionellt, varit ett manligt ansvarsområde.

Om vi förlitar oss till tidigare forskning så bör reproduktion och produktion vara två extremvärden i en könsdimension. Frågan är då om detta stämmer överens med mönster i riksdagens verklighet. För att kunna synliggöra ett eventuellt kontinuum mellan vad som kan förväntas vara mest "kvinnligt" respektive mest "manligt" har utskotten delats in i fyra grupper där social välfärd och ekonomi/teknik representerar var sin ytterpunkt. Mellan ytterpunkterna har två grupper lagts in, kultur/juridik samt basfunktioner, som i mindre grad förväntas vara könspräglade. I figur 1 åskådliggörs dimensionen mellan reproduktion och produktion. I figuren visas vilka utskott som förts till var och en av grupperna social välfärd, kultur/juridik, basfunktioner samt ekonomi/teknik.

\section{EXISTENSEN AV ETT KÖNSMÖNSTER}

För att komma fram till ett resultat som säger huruvida det existerar ett könsmönster eller ej krävs en jämförelsepunkt. I denna analys jämförs olika utskottsgrupper med varandra och då är det rimligt att ha den genomsnittliga andelen kvinnor i samtliga utskott som utgångspunkt. I den följande redovisningen betyder en underrepresentation av kvinnor således att andelen kvinnliga ledamöter inom en särskild utskottsgrupp är lägre än genomsnittet i hela utskottsorganisationen. Vice versa föreligger det en överrepresentation av kvinnor i de fall andelen kvinnliga ledamöter inom en särskild utskottsgrupp är högre än genom- 


\section{FIGUR 1. INDELNING AV RIKSDAGENS UTSKOTT EFTER ETT KONTINUUM MELLAN REPRODUKTION OCH PRODUKTION}

Reproduktion

Produktion

\section{SOCIAL VALFARD KULTUR/JURIDIK BASFUNKTIONER EKONOMI/TEKNIK}

$\begin{array}{cccc}\text { utskott: } & \text { utskott: } & \text { utskott: } & \text { utskott: } \\ \text { social } & \text { kultur } & \text { utrikes } & \text { finans } \\ \text { socialförsäkring } & \text { justitie } & \text { försvar } & \text { skatte } \\ \text { arbetsmarknad } & \text { lag } & \text { jordbruk } & \text { näring } \\ \text { utbildning } & \text { konstitution } & \text { bostad } & \text { trafik }\end{array}$

KOMMENTAR: Utskottens ansvarsområden 1) Gruppen social välfärd. Socialutskottet: hälsovård, sjukvård och social omsorg. Socialförsäkringsutskottet: invandrare och flyktingar, ekonomisk trygghet vid sjukdom och handikapp, ekonomisk trygghet vid ålderdom och ekonomisk trygghet för familjer och barn. Arbetsmarknadsutskottet: ekonomisk trygghet vid arbetslöshet samt arbetsmarknad och arbetsliv. Utbildningsutskottet: studiestöd, utbildning och universitetsforskning. 2) Gruppen kultur/juridik. Kulturutskottet: kultur, medier, trossamfund och fritid. Justitieutskottet: rättsväsendet. Lagutskottet: lagstiftningsfrågor. Konstitutionsutskottet: rikets styrelse. 3) Gruppen basfunktioner. Utrikesutskottet: utrikesförvaltning och internationell samverkan samt internationellt bistånd. Försvarsutskottet: totalförsvar. Jordbruksutskottet: allmän miljö- och naturvård samt jord- skogsbruk, fiske med anslutande näringar. Bostadsutskottet: samhällsplanering, bostadsförsörjning och byggande. 4) Gruppen ekonomi/teknik. Finansutskottet: samhällsekonomi och finansförvaltning, allmänna bidrag till kommunerna, statsskuldsräntor samt avgifter till Europeiska gemenskaperna. Skatteutskottet: skatteförvaltning och uppbörd. Näringsutskottet: regional utjämning och utveckling, energi och näringsliv. Trafikutskottet: kommunikationer. Beskrivningen bygger på vilka ärenden inom den statliga budgeten som respektive utskott hanterar. Ur riksdagens ledamotsförteckning 1999/ 2000 .

snittet bland samtliga utskott. Tabell 1 visar könsmönster i riksdagens utskott år 19712000. Jämförelsemåttet visar avvikelser från genomsnittet.

Huvudresultatet av tabellen är att det i stort sett under hela perioden 1971-2000 förekommit en överrepresentation av kvinnor i utskott inom politikområdena social välfärd och kultur/juridik. På motsvarande sätt har det förekommit en underrepresentation av kvinnor inom politikområdena basfunktioner och ekonomi/teknik. Myntets andra sida är att det samtidigt varit frågan om en underrepresentation av manliga ledamöter inom politikområdena social välfärd och kultur/juridik, samt en över- representation inom politikområdena basfunktioner och ekonomi/teknik.

De två områden som framstår som varandras motpoler är social välfärd och ekonomi/teknik. Mandatperioden 1988/91 var den genomsnittliga andelen kvinnor inom utskottsgruppen social välfärd 54 procent, samtidigt var den 21 procent inom gruppen ekonomi/teknik. Skillnaden på 33 procentenheter är den största som återfinns i materialet. På de två områdena kultur/juridik samt basfunktioner, som getts en mellanposition i modellen reproduktion-produktion, framträder könsskillnaderna med mindre skärpa, vilket också var det förväntade resultatet. I figur 2 fokuseras de två yt- 


\section{TABELL 1. KÖNSMÖNSTER I RIKSDAGENS UTSKOTT 1971-2000}

\begin{tabular}{|c|c|c|c|c|c|c|c|c|c|c|}
\hline område & social & älfärd & kultur/ & 'juridik & basfu & ktioner & ekon & $\mathrm{mi} /$ & an & \\
\hline $\begin{array}{l}\text { mandat- } \\
\text { period }\end{array}$ & $\begin{array}{l}\text { andel } \\
\text { kvinno }\end{array}$ & $\begin{array}{l}\text { jfr. } \\
\text { mått }\end{array}$ & $\begin{array}{c}\text { andel } \\
\text { kvinnor }\end{array}$ & $\begin{array}{l}\text { jfr. } \\
\text { mått }\end{array}$ & $\begin{array}{c}\text { andel } \\
\text { kvinnor }\end{array}$ & $\begin{array}{l}\text { jfr. } \\
\text { mått }\end{array}$ & $\begin{array}{c}\text { andel } \\
\text { kvinnor }\end{array}$ & $\begin{array}{l}\text { jfr. } \\
\text { mått }\end{array}$ & $\begin{array}{l}\text { snitt } 16 \\
\text { utskott }\end{array}$ & $\begin{array}{r}\text { riksda } \\
\text { total }\end{array}$ \\
\hline $1971 / 73$ & 20 & +5 & 24 & +9 & 9 & -6 & 5 & -10 & 15 & 14 \\
\hline $1974 / 76$ & 22 & +6 & 23 & +7 & 15 & -1 & 5 & -11 & 16 & 21 \\
\hline $1976 / 79$ & 19 & 0 & 26 & +7 & 24 & +5 & 8 & -11 & 19 & 23 \\
\hline $1979 / 82$ & 29 & +7 & 27 & +5 & 21 & -1 & 13 & -9 & 22 & 28 \\
\hline $1982 / 85$ & 39 & +13 & 34 & +8 & 20 & -6 & 12 & -14 & 26 & 28 \\
\hline $1985 / 88$ & 42 & +13 & 36 & +7 & 22 & -7 & 18 & -11 & 29 & 32 \\
\hline $1988 / 91$ & 54 & +19 & 41 & +6 & 24 & -11 & 21 & -14 & 35 & 38 \\
\hline $1991 / 94$ & 49 & +16 & 41 & +8 & 25 & -8 & 15 & -18 & 33 & 33 \\
\hline $1994 / 98$ & 47 & +3 & 49 & +5 & 42 & -2 & 36 & -8 & 44 & 43 \\
\hline $1998 / 00$ * & 49 & +4 & 50 & +5 & 40 & -5 & 40 & -5 & 45 & 44 \\
\hline
\end{tabular}

KOMMENTAR: Politikområdet social välfärd omfattar: social-, socialförsäkrings-, arbetsmarknads- och utbildningsutskottet; kultur/juridik omfattar kultur-, justitie-, lag- och konstitutionsutskottet; basfunktioner omfattar utrikes-, försvars-, jordbruks- och bostadsutskottet; ekonomi/teknik omfattar finans-, skatte-, närings- och trafikutskottet. Samtliga siffror i tabellen visar ett genomsnitt för respektive mandatperiod. Beräkningen har skett utifrån årliga uppgifter och omfattar endast ordinarie utskottsledamöter. Jämförelsemåttet jämför andel kvinnliga ledamöter i utskotten inom respektive politikområde med genomsnittlig andel kvinnor i hela utskottsorganisationen. $(+)$ tecken betyder att kvinnliga ledamöter varit överrepresenterade i förhållande till genomsnittet, (-) tecken att de varit underrepresenterade. Antalet ordinarie ledamöter i varje utskott är 15 förutom mandatperioderna 88/91, 94/98 samt den innevarande mandatperioden 98/02* då antalet är 17. (*) mandatperioden ej avslutad. 1994 förlängdes mandatperioden till fyra år dess för innan var den tre år. Fram till valet 1976 påbörjade den nyvalda riksdagen sitt arbete efter nyår därefter i direkt anslutning till valet i september. I beräkningen av andel kvinnor i riksdagen totalt har hänsyn tagits till ersättare för statsråd och talman. Källa: Riksdagens ledamotsförteckningar.

terligheterna: politikområdena social välfärd och ekonomi/teknik. Beräkningarna utgår från jämförelsemåttet $\mathrm{i}$ tabell 1 .

Den grafiska framställningen gör det lättare att se det mönster som föreligger. Den kurva som visar överrepresentation av kvinnor inom området social välfärd är som en spegelbild till den kurva som visar underrepresentation inom området ekonomi/teknik. Linjerna befinner sig på ungefär samma avstånd från mitt/nollpunktslinjen som står för andel kvinnliga ledamöter bland samtliga 16 utskott. Två brytpunkter skall dock framhållas. Den ena framkommer i slutet av 1970-talet. Där verkar det som att det sker en ökad polarisering mellan kurvorna. Den andra brytpunkten framkommer vid valet 1994: där börjar linjerna stråla samman.

I figur 2 framstår alltså 1980-talet som det årtionde då det förelåg en särskilt tydlig uppdelning av kvinnligt och manligt i utskotten. Detta är något som bekräftas i en mer formaliserad beräkning av hur starkt könsmönstret framträtt vid olika tidpunkter. Effekten av kön blir starkare över tid för att avta efter 1994 års val (Wängnerud 1998, 61).

\section{KÖNSMÖNSTRENS FRAMVÄXT OCH TILLBAKAGÅNG}

Jag skrev tidigare att marginalisering och 


\section{FIGUR 2. KVINNOREPRESENTATION I UTSKOTT INOM POLITIKOMRÅDENA SOCIAL VÄLFÄRD OCH EKONOMI/TEKNIK 1971-2000}

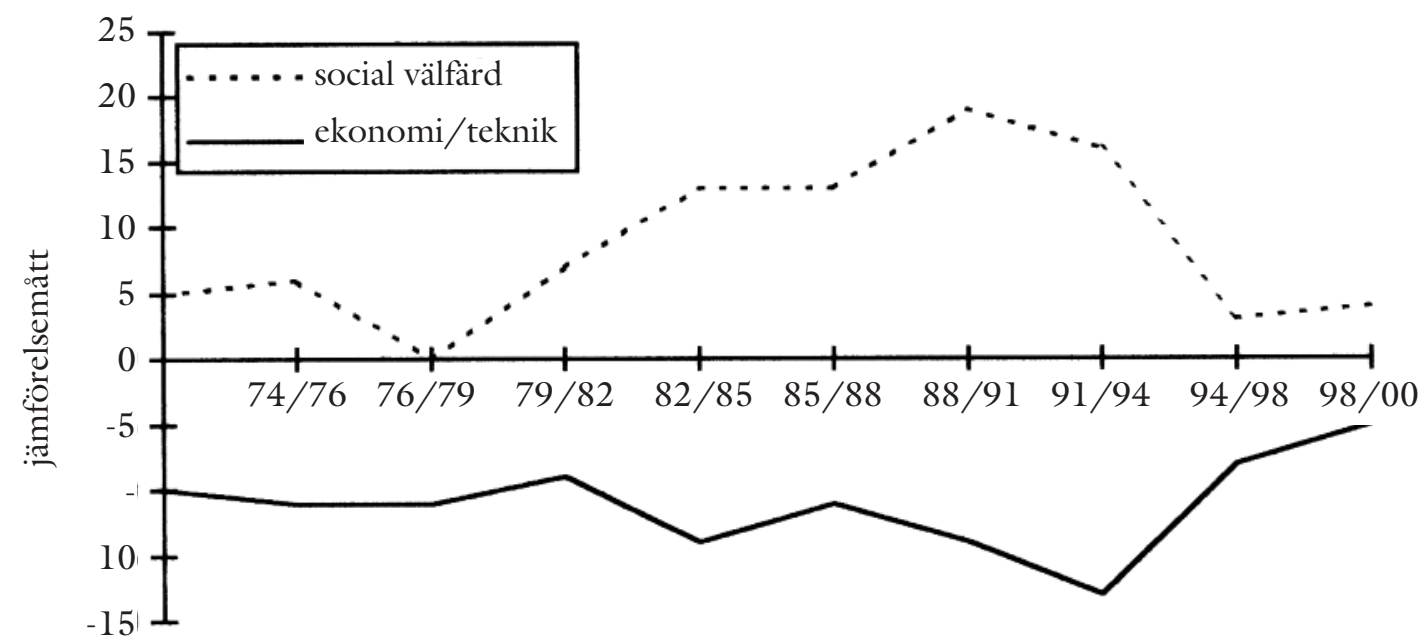

mandatperiod

KOMMENTAR: Jämförelsemåttet jämför andel kvinnliga ledamöter inom respektive politikområde med genomsnittlig andel kvinnor i hela utskottsorganisationen. (+) tecken betyder överrepresentation av kvinnor i förhållande till genomsnittet, (-) tecken betyder underrepresentation. Figuren startar med mandatperioden 1971/73. Politikområdet social välfärd omfattar social-, socialförsäkrings-, arbetsmarknads och utbildningsutskottet; ekonomi/teknik omfattar finans-, skatte-, närings- och trafikutskottet. Den sista mandatperioden ej avslutad. Källa: Riksdagens ledamotsförteckningar.

inkludering är fenomen som är svåra både att definiera och exakt mäta. Jag liknade utskotten vid ett lackmuspapper. Det är framförallt genom att komma närmare orsakerna till könsmönstrens framväxt och tillbakagång som vi kan få en indikator på förekomsten av marginalisering respektive inkludering. Marginalisering handlar om ett åsidosättande. Jag tänker mig att om det är på det sättet att kvinnliga politiker inte får igenom sina önskemål om utskottsuppdrag i lika stor utsträckning som manliga politiker, och om de förändringar som genomförs sker ovanför deras huvuden, då kan man dra slutsatsen att kvinnor generellt sett är mer marginaliserade än män. Det är nästan omöjligt att definiera marginalisering i absoluta termer, åtminstone på det område som undersöks här. Kvinnor som grupp kan vara mer marginaliserade än män som grupp och marginaliseringen kan vara mer eller mindre framträdande vid olika tidpunkter. Det är i sådana relativa termer som jag valt att försöka fastställa förekomsten av marginalisering eller inkludering.

Tidigare har det framkommit två brytpunkter av särskilt intresse: slutet av 1970talet, när polariseringen mellan kvinnliga och manliga politikområden börjar bli markant, och valet 1994, när polariseringen avtar. Vid statsvetenskapliga institutionen, Göteborgs universitet, genomförs regelbundet undersökningar av riksdagen. Vid tre tillfällen 1985, 1988 och 1994 har följande fråga ställts till riksdagsledamöterna: “Om Du fick välja helt fritt, vilket riks- 
dagsutskott skulle Du då helst vara ordinarie ledamot av?" En analys visar att vid samtliga tre tillfällen har kvinnliga ledamöter i stor utsträckning önskat sig till utskott inom gruppen social välfärd och manliga ledamöter, i sin tur, i stor utsträckning önskat sig till utskott inom gruppen ekonomi/teknik (Wängnerud 1998, 89).

År 1985 önskade sig 42 procent bland de kvinnliga ledamöterna till utskott inom gruppen social välfärd, samtidigt var det 15 procent bland de manliga ledamöterna som önskade sig dit, vilket ger en könsskillnad på 27 procentenheter. År 1988 var motsvarande siffror 39 procent bland kvinnliga och 17 procent bland manliga ledamöter vilket ger en könsskillnad på 22 procentenheter; år 1994 vara andelen 39 procent bland kvinnliga och 16 procent bland manliga ledamöter vilket ger en könsskillnad på 23 procentenheter.

När det gäller området ekonomi/teknik föreligger det i stort sett en spegelbild till de könsskillnader som just radats upp: år 1985 var det 24 procent bland de kvinnliga och 43 procent bland de manliga ledamöterna som önskade sig dit, vilket ger en könsskillnad på 19 procentenheter. År 1988 var motsvarande siffror 25 procent bland kvinnliga och 42 procent bland manliga ledamöter vilket ger en könsskillnad på 17 procentenheter; år 1994 var andelen 22 procent bland kvinnliga och 49 procent bland manliga ledamöter vilket ger en skillnad på 27 procentenheter. På områdena kultur/juridik och basfunktioner har däremot könsskillnaderna i önskemål i stort sett varit försumbara.

Utöver resultaten ovan finns det några viktiga slutsatser att ta fasta på. Även om det föreligger en könsskillnad på området ekonomi/teknik så har det samtidigt varit en relativt stor andel kvinnliga ledamöter, cirka en fjärdedel, som önskat sig dit. Tittar man närmare på resultaten så har önskemålen bland kvinnor fördelat sig ungefär hälften/hälften om man ställer å ena sidan grupperna social välfärd och kultur/juridik mot å andra sidan grupperna basfunktioner och ekonomi/teknik. Bland manliga ledamöter ser mönstret annorlunda ut. Där har det varit drygt två tredjedelar som önskat sig till utskott inom gruppen basfunktioner eller ekonomi/teknik och knappt en tredjedel som önskat sig till utskott inom grupperna social välfärd eller kultur/juridik. Sammantaget går det att konstatera att manliga politikers önskemål generellt sett varit mer koncentrerade än kvinnliga politikers önskemål och att männen därvidlag är de mest könstypiska. Ett slående resultat är att det varit förhållandevis få män som önskat sig plats i utskott inom gruppen social välfärd.

Innan jag drar några mer långtgående slutsatser av redovisningen ovan skall vi ta del av en analys som visar i vilken utsträckning kvinnor och män fått igenom sina önskemål (Wängnerud 1998, 99). Här framkommer en förändring över tid. År 1985 var det en betydligt större andel män än kvinnor som fick igenom sina önskemål: 52 procent bland männen och 28 procent bland kvinnorna, det vill säga en skillnad på 24 procentenheter. År 1988 hade könsskillnaden minskat till nio procentenheter men fortfarande var det en större andel män än kvinnor som fick igenom sina önskemål ( 54 procent bland männen och 45 procent bland kvinnorna). År 1994 var däremot fördelningen jämn: 49 procent bland kvinnorna och 48 procent bland männen fick igenom sina önskemål vilket ger en könsskillnad på endast en procentenhet.

Frågan är då vad som ligger bakom denna förändring. Det är inte så att kvinnors och mäns önskemål förändrats särskilt mycket - där var som vi tidigare sett könsskillnaderna ungefär lika stora 1994 som 1985. Orsakerna står istället att finna på en institutionell nivå. I en mer omfattande analys (Wängnerud 1998, 103) har jag kunnat konstatera att år 1985 var det svårare för kvinnor än för män att få igenom sina önskemål på samtliga fyra områden: social välfärd, kultur/juridik, basfunktioner samt ekonomi/teknik. Vad som händer till år 1988 är 


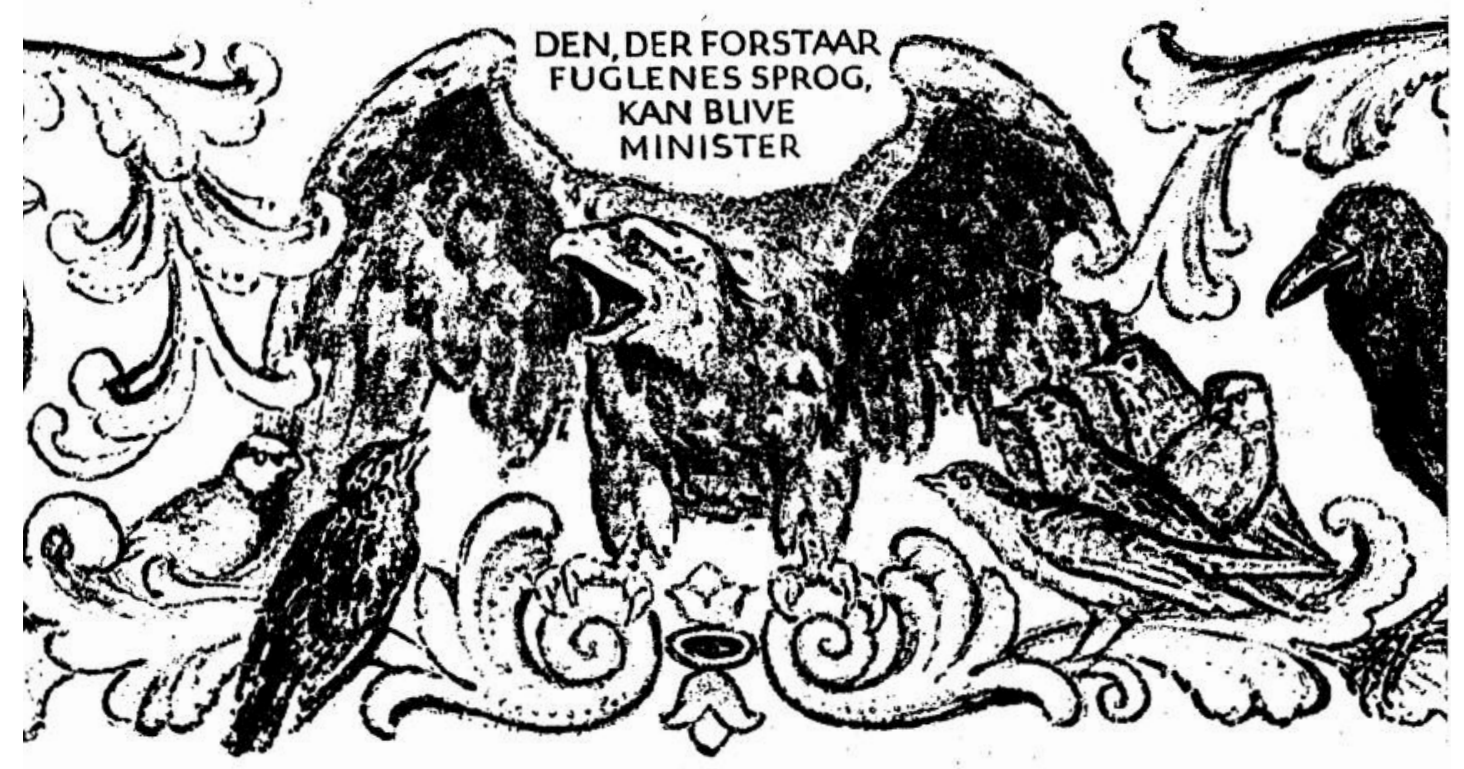

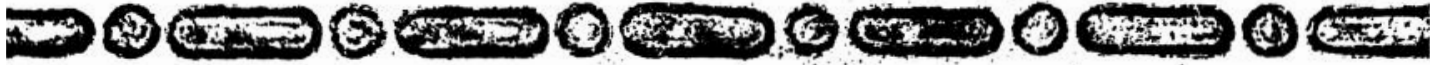

Friserne udenfor folketingssalen med de gyldne ordsprog kan godt sige et og andet om situationenn.

att kvinnor i högre grad än tidigare släpps in på de mest "kvinnliga" områdena social välfärd och kultur/juridik; där hade kvinnor det lättare än män att få igenom sina önskemål detta år, medan de fortfarande hade det svårare att komma in på de mest "manliga" områdena basfunktioner och ekonomi/teknik. Till år 1994 hade ytterligare förändringar ägt rum: detta år var det svårast att fă igenom sina önskemål för de kvinnor som ville in på området social välfärd. På de andra tre områdena fanns ingen könsskillnad alls eller så var det lättare för kvinnor än för män att ta sig in i mest önskat utskott.

Jag skall inte förlora mig i detaljer. Den utveckling som äger rum kan karakteriseras som att den går från diskriminering av kvinnor till stereotypisering och sedan jämlik behandling. Även om denna utveckling till viss del skett på bekostnad av de kvinnliga politiker som har de mest typiskt kvinnliga önskemålen så har den överlag inneburit att fler kvinnor än tidigare fătt igenom sina önskemål.

När jag skriver att orsakerna till förändringen står att finna på institutionell nivå så grundar jag det bland annat i en intervjuomgång jag genomförde med ett antal riksdagsledamöter våren 1994 (Wängnerud 1998, 65ff). Flera partier drev kampanjer om "varannan damernas" inför valet hösten 1994. Varannan damernas stod framförallt för en satsning på varvade listor på valsedlarna. Men särskilt de kvinnliga ledamöter jag intervjuade såg det som en självklarhet att kampanjen också skulle gälla interna politiska uppdrag. I artikeln "From a Small to a Large Minority. Women in Scandinavian Politics" framhåller Drude Dahlerup (1988) betydelsen av kritiska handlingar för att förändringar i kvinnliga politikers villkor skall äga rum. Det är sådana kritiska handlingar som kommit till uttryck här. Platserna i utskotten fördelas centralt av de oli- 
ka partiernas ledningsgrupper i riksdagen. Det är via dessa knutpunkter som en medveten satsning på jämlikhet mellan könen ägt rum.

\section{SLUTDISKUSSION}

Jag skall börja med att klargöra denna slutdiskussion genom att säga att det inte varit utskotten i sig som varit intressanta i denna analys. Jag har använt utskotten som indikator på mer omfattande, men samtidigt mer svårfångade fenomen. Utskotten är naturligtvis inte den enda möjliga indikatorn på marginalisering eller inkludering av kvinnor i politiken, men jag menar ändå att de är en god indikator, då det handlar om centrala arenor med betydande makt.

Det är svårt att veta hur generell den utveckling är som beskrivits i denna analys: är till exempel år 1985 ett extremt undantag som det inte går att dra några större växlar på? Ett argument för att det inte skulle handla om några tillfälligheter är att resultatet om en utveckling från diskriminering till jämlik behandling återfinns på ett genomgripande sätt då materialet bryts ned och kontroller görs för betydelsen av sådant som politikernas partitillhörighet, ålder och riksdagserfarenhet (antal år i riksdagen). Om det rörde sig om slumpartade skeenden borde resultaten variera mellan olika undergrupper. Istället är det, men några få undantag, samma tendenser som framkommer överallt. Utjämningen i utskotten ser också annorlunda ut idag än till exempel i början av 1970-talet. Under 1970-talet var kvinnor framförallt samlade i utskott inom området kultur/juridik vilket hör till de mindre eftertraktade politikområdena.

Min huvudsakliga slutsats är att kvinnliga politiker idag kan betraktas som inkluderade i den svenska riksdagen. Det framkommer inga resultat som tyder på att kvinnor efter valet 1994 skulle vara åsidosatta på något särskilt vis. Därmed inte sagt att det råder någon total jämlikhet mellan könen när det gäller möjligheter till makt och inflytande.
Någon sådan slutsats håller inte undersökningen för. Poängen är att jämlikheten ändå förefaller vara så pass stor att det är meningsfullt att gå vidare och undersöka konsekvenser av den ökade kvinnorepresentation på andra parlamentariska arenor som exempelvis den politiska dagordningen.

Jag skall avsluta denna artikel med att vidga diskussionen om könsmönster något. Det är skillnad på att undersöka en arena som utskotten, vilket jag gjort här, och en arena som den politiska dagordningen, vilket exempelvis är den arena som Anne Phillips teori i boken The Politics of Presence (1995) kretsar kring. Kärnan i teorin om närvarons politik är att det behövs kvinnliga representanter i parlamentet för att kvinnors intressen skall få genomslag. Phillips skriver:

"There are particular needs, interest, and concerns that arise from women's experience, and these will be inadequately addressed in a politics that is dominated by men. Equal rights to a vote have not proved strong enough to deal with this problem; there must also be equality among those elected to office." (Phillips

$1995,66)$

Det jag vill betona är att alla könsmönster inte kan tolkas eller hanteras på samma sätt. Det kan fortfarande vara så att kvinnor, trots att de befinner sig på samma typ av positioner som män, driver andra intressen än män och därmed påverkar politikens inriktning. Olika typer av könsmönster måste förstås i sina särskilda sammanhang.

För att man skall kunna dra slutsatser om teorin om närvarons politik behöver utskottsanalyserna kompletteras med annat material. Men jag kan ändå sträcka mig så långt som att säga att teorin om närvarons politik redan på grundval av vad som framkommit här kan ges ett visst stöd. Ett viktigt sidoresultat av denna undersökning är att det finns en annan typ av prioriteringar bland kvinnliga än bland manliga politiker. Det område jag kallat social välfärd har hög prioritet bland kvinnor men inte bland män. Om 
man skall spekulera mer fritt så kan det finnas anledning att varna för en utveckling där allt för mycket kraft läggs ned på att få in kvinnliga politiker på mäns traditionella områden. Risken är att det bildas ett "hål" där kvinnorna tidigare varit. Närvaron måste vara ömsesidig. I lika hög grad som kvinnor engagerar sig på mäns områden måste män engagera sig på kvinnors områden. Åtskilliga väljarundersökningar (Oskarson \& Wängnerud 1995,1996 ) har visat att olika typer av omsorgspolitiska frågor, som socialpolitik och familjepolitik, befinner sig högt upp på de kvinnliga medborgarnas agenda. Från en demokratisk utgångspunkt kan man knappast försvara att kvinnliga medborgares prioriteringar och åsikter skulle få mindre genomslag i det politiska livet än manliga medborgares prioriteringar och åsikter. Det behövs politiker som engagerar sig i och driver även dessa frågor.

\section{REFERENSER}

- Bergqvist, Christina m.fl. (red.) (1999): Likestilte demokratier? Kjonn og politikk i Norden. Nordisk Ministerråd. Universitetforlaget, Oslo.

- Dahlerup, Drude (1988): "From a Small to a Large Minority. Women in Scandinavian Politics", i Scandinavian Political Studies, 4: 275(98.

· Esaiasson, Peter \& Sören Holmberg (1996): Representation from Above. Members of Parliament and Representative Democracy in Sweden. Aldershot, Dartmouth.

- Haavio-Mannila, Elina m.fl. (red.) (1983): Det uferdige demokratiet. Kvinner i nordisk politikk Nordisk Ministerråd, Oslo.

- Hirdman, Yvonne (1990): “Genussystemet”, i Demokrati och makt i Sverige. Maktutredningens buvudrapport (SOU 1990: 44) Allmänna Förlaget, Stockholm.

· Jonäng, Gunnel (1996): “Gunnel Jonäng”, i Riksdagsutskotten inifrain. Tretton ledamöters hågkomster. Riksbankens Jubileumsfond, Gidlunds. . Norris, Pippa (1996): "Legislative Recruitment", i LeDuc, L., Niemi, R.G. \& Norris, P. Comparing Democracies. Elections and Voting in Global Perspective Sage, London.

- Oskarson, Maria \& Lena Wängnerud (1995): Kvinnor som väljare och valda. Om betydelsen av kön $i$ svensk politik Studentlitteratur, Lund.
. Oskarson, Maria \& Lena Wängnerud (1996):

"Vem representerar kvinnorna?", i Rothstein, B. \& Särlvik, B. Vetenskapen om politik. Festskrift till professor emeritus Jörgen Westerståhl. Göteborgs universitet: Statsvetenskapliga institutionen.

- Phillips, Anne (1995): The Politics of Presence Clarendon Press, Oxford.

- Sannerstedt, Anders (1992): Förhandlingar i riksdagen Lund University Press, Lund.

- Skjeie, Hege (1992): Den politiske betydningen av kjønn. En studie av norsk topp-politikk rapport 92:

11 Institutt for samfunnsforskning, Oslo.

- Thomas, Sue (1994): How Women Legislate

Oxford University Press, Oxford.

. Wängnerud, Lena (1996): "Intressen kontra stereotyper. Varför finns det kvinnliga och manliga politikområden i riksdagen?, i Statsvetenskaplig tidskrift" 2: 129-49.

· Wängnerud, Lena (1998): Politikens andra sida. Om kvinnorepresentation i Sveriges riksdag Göteborg Studies in Politics, nr 53, Göteborg.

· Wängnerud, Lena (2000): “Testing the Politics of Presence. Women's Representation in the Swedish Riksdag", i Scandinavian Political Studies, 1, 67-91.

\section{SUMMARY}

The article analyses gender structures in standing committees in the Swedish parliament. The committees are classified into four groups based on a continuum from reproduction to production: social welfare, culture/ law, basic functions and economy/technology. The data reveals that women have been over-represented in social welfare committees and under-represented in economy/ technology committees. Within the culture/ law and basic functions groups, the gender structure has been less clear. The main result is, however, that since the 1994 Swedish general election this gender division has become less distinct. Based on surveys among Swedish Members of Parliament, it is concluded that shrinking gender structures coincide with higher awareness of questions on gender equality. This development is characterised as going from discrimination to equal treatment of female MPs.

Lena Wängnerud, fil.dr., Statsvetenskapliga institutionen, Göteborgs Universitet. 